\title{
Slovenski zdravstveni sistem in javni sektor ${ }^{1}$
}

\author{
UDK: $351.77: 614.2(497.12)$
}

\section{Marko Kranjec}

Univerza v Ljubljani, Fakulteta za upravo

marko.kranjec@fu.uni-Ij.si

\begin{abstract}
IZVLEČEK
Avtor kritično obravnava belo knjigo ministrstva za zdravje, v kateri se predlaga reforma zdravstvenega sistema Slovenije. Strinja se s potrebo po reformi, ki bo imela pomembne posledice tudi za javni sektor, pri čemer pa meni, da reforma zdravstva ni samo sprememba financiranja, kar je glavni poudarek v beli knjigi, temveč je treba rešiti številna vsebinska vprašanja učinkovitosti izvajalcev in regulatorjev, predvsem pa odgovoriti na vprašanje prihodnje organizacije izvajalcev in njihovega lastništva. $Z$ analizo ekonomskih, javnofinančnih, regulatornih in upravljavskih vidikov reforme avtor pokaže, da je treba predhodno odgovoriti na naslednja vprašanja: i) kakšna je učinkovitost in organiziranost izvajalcev v sedanjem sistemu, ii) kolikšne so finančne rezerve obstoječega sistema, iii) kako vzpostaviti učinkovit sistem ekonomske regulacije, iv) kakšne zakonodajne spremembe so potrebne in v) kakšni drugi ukrepi so potrebni za učinkovito izvedbo reforme. Predlaga nadaljevanje priprav na reformo (Bela knjiga II), s čimer bi bilo pripravljeno izhodišče za njeno kakovostno izvedbo.
\end{abstract}

Ključne besede: ekonomika zdravstva, zdravstvena ekonomika, javni sektor, javne finance, ekonomska regulacija, privatizacija, javni zavodi.

\section{Uvod}

Razprave o reformi slovenskega zdravstvenega sistema kažejo, da obstajajo velike razlike $\vee$ pogledih, ali naj zdravstvo ostane pretežno del javnega sektorja ali pa je treba pričeti resno razmišljati o privatizaciji zdravstva ob upoštevanju njegove specifične vloge $v$ zadovoljevanju potreb in uresničevanju načela pravičnosti in solidarnosti. Med zdravniki prevladuje mnenje, da morajo izvajalci zdravstvenih storitev ostati tako kot doslej pretežno $v$ javnem sektorju in $v$ organizacijski obliki negospodarskih javnih zavodov, med ekonomisti pa se vedno bolj uveljavlja mnenje, da je potreben temeljit razmislek o prihodnji organiziranosti zdravstvenih izvajalcev, predvsem $v$ smeri zdravstvenih podjetij, ki naj poslujejo tako $v$ javnem kot $v$ zasebnem sektorju.

1 Članek je razširjeni povzetek analize, ki jo je avtor izdelal za ministrstvo za finance in ki je bila deloma objavljena $v$ Zborniku referatov za posvetovanje ekonomistov in zdravnikov o reformi slovenskega zdravstvenega sistema (Portorož, september 2003, Društvo ekonomistov Ljubljana, Ekonomska fakulteta Ljubljana in Zdravniška zbornica Slovenije). 


\section{Marko Kranjec}

\section{Slovenski zdravstveni sistem in javni sektor}

Bela knjiga (BK) ministrstva za zdravje (MZ), s katero se predvideva reforma zdravstvenega sistema, na ta vprašanja ne daje jasnih odgovorov. Pretežno se ukvarja z reformo sistema financiranja in implicitno predpostavlja nespremenjen sistem organizacije zdravstvenih izvajalcev, ki naj bi ostali pretežno $v$ javnem sektorju. Priznava sicer, da je sedanji način upravljanja negospodarskih javnih zavodov vodil do neučinkovitosti (spomnimo se samo nakupa kirurških postelj, nabave plenic, plačevanja dragih zdravil itd.), za katere pa prevladuje prepričanje, da jih je mogoče odpraviti z večjo zavestjo zaposlenih in z manjšimi korekturami sedanjega sistema.

Ekonomisti so po drugi strani prepričani, da je BK dokument, ki ne bo omogočil potrebnih izboljšav sistema, zaradi česar je potreben resnejši razmislek o prihodnjih korakih. Namen sestavka je zato prikazati glavne pomanjkljivosti BK, kot jih vidijo ekonomisti, in predlagati smeri nadaljnjega dela pri reformi sistema. Članek je razdeljen na dva dela: $v$ točki 2 je narejena kritična analiza BK, $v$ točki 3 pa so podani nekateri predlogi za nadaljnje delo. Sledi kratek zaključek $\vee 4$. točki.

\section{Kritična ocena BK}

BK je strukturirana $v$ šestih poglavjih, od katerih se vsako nanaša na enega od ciljev reforme. Ti so:

1. pravičnost pri zagotavljanju sredstev za zdravstveno varstvo,

2. razporejanje sredstev po potrebah državljanov,

3. boljša dostopnost do zdravstvenega varstva,

4. razvoj sistema celovite kakovosti,

5. regulacija sistema in učinkovitost upravljanja in

6. krepitev področja javnega zdravstva.

Cilji reforme odsevajo probleme, ki so posledica demografskih, socialnih, ekonomskih, političnih in zdravstvenih sprememb in se pojavljajo praktično $v$ vseh državah, vključno s Slovenijo. S tega stališča zato ciljem ni mogoče oporekati; pomembnejša je strategija za dosego teh ciljev, ki jo je smiselno ocenjevati z ekonomskega, javnofinančnega, regulativnega in upravljavskega vidika. $S$ teh vidikov pa BK ni mogoče oceniti kot ustrezno izhodišče za reformo.

\subsection{Ekonomski vidik reforme}

BK je pisana z izrazito negativnim stališčem do ekonomike in ekonomistov. Na več mestih so ekonomisti in njihova stališča omenjeni kot nekakšna ovira za večjo pravičnost in učinkovitost javnega sektorja $\vee$ zdravstvu. To je verjetno posledica 
dejstva, da so njeni avtorji pretežno zdravniki, ${ }^{2}$ ki jim je ideja, da je zdravstvo dejavnost, pri kateri je treba upoštevati ekonomsko logiko in ekonomske omejitve, težko sprejemljiva. Po drugi strani pa je - paradoksalno - knjiga polna primerov, ki kažejo, kako močno so $v$ zdravstvu prisotne ekonomske reakcije, ki skoraj učbeniško ustrezajo ekonomski teoriji in se jih avtorji morda niti ne zavedajo. To je mogoče ugotoviti na različnih mestih $v$ knjigi, kjer se pojavljajo nesmiselne ekonomske trditve.

BK izhaja iz (napačne) trditve, da je zdravstveni trg zelo specifičen in zanj ne veljajo klasični ekonomski zakoni. Ker ni pojasnjeno, kaj so »klasični ekonomski zakoni«, domnevamo, da imajo avtorji $\vee$ mislih trg, ponudbo, povpraševanje in cene. Res je, da $\vee$ zdravstvu zaradi več razlogov ne deluje konkurenčni trg, kot ga postulira ekonomska teorija, ne drži pa trditev, da zato ne veljajo ekonomske zakonitosti. Višja cena tudi v zdravstvu pomeni večjo ponudbo in manjše povpraševanje, nižja cena pa manjšo ponudbo in večje povpraševanje. To je razvidno iz številnih primerov, ki jih navaja sama BK, od katerih naj omenimo samo nekatere:

- podaljševanje bivanja $v$ bolnišnicah pri plačevanju po oskrbnih dneh,

- pošiljanje pacientov k specialistom v modelu glavarinskega plačevanja,

- dvakratno zaračunavanje istih zdravil od bolnišnic,

- prizadevanje bolnišnic, da bi bile plačane po kapacitetah namesto po storitvah,

- skrajševanje ležalnih dni v bolnišnicah s prehodom na model plačevanja po primeru itd.

Številne študije $v$ tujini, $v$ katerih so bile empirično ocenjene reakcije izvajalcev zdravstvenih storitev in pacientov na spremenjene modele plačevanja (ekonomisti temu pravijo dohodkovne in cenovne elastičnosti ponudbe in povpraševanja) jasno kažejo, da "klasični ekonomski zakoni « še zmeraj veljajo in da ekonomike v zdravstvu ni mogoče odpraviti z njenim ignoriranjem. Ekonomski zakoni veljajo vedno in povsod, na vseh zemljepisnih širinah in pri vseh dejavnostih, in seveda tudi v zdravstvu v Sloveniji, kar jasno potrjujejo zgoraj nanizani primeri.

$\checkmark$ čem je zdravstvo specifično glede na trg in ekonomiko? Za zdravstvo je značilna velika negotovost (uncertainty) glede nastopa bolezni, poteka zdravljenja, stroškov, delovanja zdravil in še številnih drugih dejavnikov. ${ }^{3} \vee$ takšnih razmerah ne obstajajo ustrezne informacije, ki so potrebne za delovanje trga, zato tako na področju izvajanja (ponudbe zdravstvenih storitev) kot na področju financiranja težko

2 Od 32 navedenih avtorjev je 20 doktorjev medicine, 5 uslužbencev ministrstva za zdravstvo in le 4 so ekonomisti. Že samo število avtorjev je lahko problematično za konsistentnost teksta. Poleg avtorjev je navedenih še 43 sodelavcev, med katerimi je več kot polovica zdravnikov.

$3 \mathrm{Na}$ negotovost kot odločilen vzrok specificnosti zdravstva je prvi opozoril nobelovec K. Arrow v svojem klasičnem članku. Zanimivo je, da bela knjiga v svojem zanikanju ekonomike $v$ zdravstvu uporablja koncepte, ki so jih razvili prav ekonomisti, ko so proučevali, zakaj trg $v$ nekaterih dejavnostih deluje nezadovoljivo, tj. informacijsko asimetrijo, moralni hazard in negativno selekcijo; Arrow, K. (1963), Stiglitz (1981). 
Marko Kranjec

\section{Slovenski zdravstveni sistem in javni sektor}

organiziramo trg, ki bi vodil do teoretično učinkovite "alokacije», in to predvsem zaradi treh razlogov: i) obstaja informacijska asimetrija med ponudniki in povpraševalci. Na področju izvajanja so zaradi boljše informiranosti v prednosti ponudniki (zdravniki) pred povpraševalci, na področju financiranja (zavarovanja zdravstvenih tveganj) pa povpraševalci pred ponudniki (zavarovalnicami). Zaradi te asimetrije trg ali ne obstaja ali deluje defektno; ii) zdravstvo ima pomembne eksterne učinke, zaradi katerih je zaželena in potrebna družbena intervencija (javno zdravstvo, nalezljive bolezni); in iii) problem zdravstva je navsezadnje problem pravičnosti. Zaradi teh razlogov vse države intervenirajo predvsem na področju financiranja z obveznimi javnimi zavarovalnicami in deloma tudi na področju izvajanja z javnimi zdravstvenimi zavodi. ${ }^{4}$ Zaradi uresničevanja načela pravičnosti je dejansko večji problem financiranje (zavarovanje) zdravstva, medtem ko je izvajanje - vsaj v tržnih gospodarstvih pretežno prepuščeno zasebnemu sektorju ob intenzivni regulaciji cen in standardov.

Na podlagi povedanega se je zato mogoče le pogojno strinjati s trditvijo $\vee$ BK, da je zdravstvo javna dobrina. Javne dobrine so $v$ ekonomski teoriji zelo natančno opredeljene (Kranjec, M., 2003, str. 31-32): to so dobrine, pri katerih i) ni mogoča izključitev iz porabe (tak primer je npr. javna razsvetljava) in ii) poraba enega potrošnika ne zmanjšuje porabe drugih potrošnikov. Pri večini zdravstvenih storitev ni izpolnjena ne prva ne druga zahteva, saj so zdravstvene storitve tipične individualne dobrine, ki jih trošijo individualni pacienti. Če država intervenira v zdravstvu, je to samo zaradi neekonomskih razlogov pravičnosti, defektnosti informacij in eksternalij; za vse drugo pa je ekonomski pristop edini racionalni pristop k organizaciji zdravstva. To velja tudi za štiri osnovna izhodišča BK: pravičnost, dostopnost, kakovost in učinkovitost, od katerih samo načelo pravičnosti izhaja iz širših družbenih interesov, medtem ko morajo biti druga tri izhodišča definirana primarno ekonomsko.

Če torej ne držita ideološki trditvi avtorjev, da $\vee$ zdravstvu ne delujejo »klasične " ekonomske zakonitosti oz. da je zdravje javna dobrina (to je samo delno), se tudi ni mogoče strinjati z (dogmatičnim) stališčem, da samo javni sektor lahko zagotovi pravičen in učinkovit zdravstveni sistem. Praksa reform zdravstvenih sistemov (v Nemčiji, Franciji itd.) jasno kaže, da t. i. socialni zdravstveni sistemi vedno bolj vključujejo večjo odgovornost prebivalstva za svoje zdravje in njegovo večjo finančno participacijo, seveda ob zagotavljanju izvajanja tako $v$ javnem kot $v$ zasebnem sektorju. S stališčem, kakršno zastopajo avtorji, se bo $v$ našem sistemu de facto ohranila ekonomska organizacija in razmišljanje, kakršno smo imeli $v$ prejšnjem sistemu (samo javni sektor), kar dejansko ne zagotavlja, da bodo reforme, ki so sicer potrebne, vodile do deklariranih ciljev, niti tega, da bodo doseženi potrebni finančni prihranki.

$4 \mathrm{~V}$ večini držav EU, z izjemo Velike Britanije, je pretežni del izvajalcev v zasebnem sektorju. 


\section{Slovenski zdravstveni sistem in javni sektor}

Problemi našega zdravstva, ki jih vsak dan občutimo kot pacienti, jasno kažejo, da je reforma zdravstva nujna; ni pa se mogoče strinjati z izhodiščem, da je javni sektor edini pravilni pristop za organizacije, ki $\vee$ zdravstvo ne vnaša potrebnih spodbud za povečevanje učinkovitosti $\vee$ obliki tekmovanja zasebnega in javnega sektorja ob ustrezni državni regulaciji in ki predpostavlja, da je osnovni problem zdravstvene reforme prenos financiranja iz prostovoljnega $v$ obvezno zavarovanje. Prav tako se ni mogoče zadovoljiti s splošnimi deklaracijami, ki napeljujejo na sum, da konkretni predlogi za izvedbo reforme sploh še niso pripravljeni.

Ekonomsko in družbeno izhodišče zdravstvene reforme je precej primerneje definiral J. Kornai (2001) z dvema načeloma, na katerih naj bi slonel učinkovit zdravstveni sistem:

i) načelo suverenosti posameznika, ki mora imeti pravico in možnost odločati o svojem zdravju, ne samo o izbiri zdravnika (ta pri nas ni zagotovljena ne danes ne $v$ reformiranem sistemu), temveč tudi o načinu življenja in o posledicah za zdravje, in

ii) načelo solidarnosti, ki zahteva pomoč vsakemu državljanu $v$ primeru potrebe in bolezni.

Ti dve načeli ne izhajata iz apriorističnega in ideološkega zagovarjanja javnega sektorja, kot to dela BK, temveč dopuščata možnost za financiranje in izvajanje zdravstva vsakemu, ki izpolnjuje ustrezne pogoje in ki je ekonomsko učinkovit. Načelo suverenosti potrošnika pa istočasno implicira, da nikomur ni mogoče zagotoviti neomejenega zdravstvenega varstva ne glede na posameznikov odnos do ohranjanja zdravja.

Ekonomski analizi BK je mogoče očitati tudi številne druge napake, ki so posledica ideoloških izhodišč ali namernega zavajanja. Če tezam avtorjev ustreza kakšen primer iz tujine, ga navajajo kot podkrepitev svojih apriornih prepričanj. Tako npr. brez dokazov voluntaristično navajajo oz. "domnevajo«, kdo v francoskem zdravstvenem sistemu nima dopolnilnega zavarovanja, na drugi strani pa odklanjajo navajanje primerov iz tujine, če to ni $v$ skladu z njihovim apriornim prepričanjem. Napačna je tudi razlaga stroškov zdravstvenega zavarovanja. Trditev, da $20 \%$ prebivalstva vsak trenutek povzroča $80 \%$ vseh izdatkov $v$ zdravstvu, je seveda točna, vendar je teh $20 \%$ vedno drug del populacije, kot je to vedno pri nepredvidljivih dogodkih, npr. požarih, tatvinah in nesrečah, zaradi katerih je zavarovanje sploh potrebno. ${ }^{5}$ Avtorji očitno ne želijo razumeti bistva zavarovanja, pripravljeni pa so trditi, da je takšna incidenca stroškov argument za javno zavarovanje. Nadaljnji dokaz nerazumevanja zavarovalništva je njihovo obžalovanje, da zavarovalne premije niso proporcionalne s prejemki prebivalstva (eno osnovnih zavarovalnih načel je, da so premije proporcionalne tveganju), iz česar naredijo sklep, da je treba zdravstveno zavarovanje reformirati z uvedbo novega prispevka oz. davka.

5 Zavarovanje je potrebno zaradi negotovosti, kot je že bilo pojasnjeno. 


\subsection{Javnofinančni vidik reforme}

Delež sredstev, ki jih slovenski davkoplačevalci ${ }^{\mathbf{6}}$ namenimo za zdravstvo, znaša 8,1 \% BDP, s čimer presegamo deleže številnih držav EU. Zaradi uvedenega dopolnilnega zdravstvenega zavarovanja je sorazmerno visok tudi delež zasebnih izdatkov $v$ obliki prostovoljnega zavarovanja in neposrednih plačil, ki skupaj znaša $1,92 \%$ BDP. Po deležu zasebnih izdatkov Slovenijo presega 8 držav EU, medtem ko ima 7 držav ta delež manjši. ${ }^{7}$

BK izhaja iz predpostavke, da je najvažnejši cilj reforme sprememba sistema financiranja zdravstva, tako da se odpravi sedanji sistem dopolnilnega zavarovanja s fiksno mesečno premijo in zamenja s posebnim zdravstvenim prispevkom (davkom) po stopnji 1,95 \% na brutoplače. S tem naj bi bila dosežena večja pravičnost ob sicer nespremenjenih skupnih sredstvih za zdravstvo, ker bi se $v$ absolutnem znesku povečali prispevki vseh zavarovancev, ki imajo brutoplačo nad 205.000 SIT na mesec, in zmanjšali prispevki zavarovancev, ki imajo nižje brutoplače. Tako bi se za okoli 61 \% zavarovancev stroški zdravstvenega zavarovanja zmanjšali, za okoli $39 \%$ zavarovancev pa povečali. ${ }^{\mathbf{8}}$

Sedanji sistem prostovoljnega dopolnilnega zavarovanja, ki ga ponujata dve zavarovalnici, prav gotovo ekonomsko ni primerno zasnovan. Zavarovalnici izkazujeta visoke dobičke, ki niso posledica njihove učinkovitosti, temveč oligopolnega položaja na trgu in kartelskega obnašanja, saj dvigujeta premije kljub visokim dobičkom. Reforma na tem področju bi bila zato več kot potrebna s sprejemom posebnega zakona o zdravstvenih zavarovalnicah ter z uvedbo ekonomske regulacije konkurenčnosti zavarovalnic in nadzora nad določanjem premij. Nenormalno visoka donosnost dopolnilnega zavarovanja je jasen znak, da s konkurenčnostjo na tem trgu nekaj ni v redu. Monopoliziranega trga nobena država ne sme pustiti brez regulative. To bi morala biti primarno naloga urada za varstvo konkurence pa tudi $M Z$, ne pa urada za zavarovalni nadzor, ki je primarno institucija za nadzor solventnosti zavarovalnic. Celotno področje dopolnilnega zavarovanja bi bilo zato treba ponovno proučiti glede značaja zavarovalnic (profitne ali vzajemne) in glede možnosti ponudbe posebnih skupinskih zavarovanj, s pomočjo katerih je mogoča razpršitev tveganj in kot posledica znižanje premij.

Pogojno se je mogoče strinjati s trditvijo BK, da je sedanja kombinacija obveznega zavarovanja $s$ proporcionalnim prispevkom in dopolnilnega zavarovanja $z$ nominalno fiksno premijo, ki jo zaračunavata zavarovalnici Vzajemna in Adriatic,

6 Nepomembno je, ali del prispevkov plačujejo podjetja, ker se končno to izraža v višjih cenah na trgu.

7 Mednarodne primerjave so $v$ vsakem primeru lahko zelo problematične. Slovenija še ne uporablja mednarodne klasifikacije izdatkov za zdravstvo po metodologiji OECD, kar je lahko dodaten vzrok za slabšo mednarodno primerljivost.

8 Podobni izračuni so narejeni tudi za upokojence. 
distribucijsko regresivna, ker premija zajema večji delež dohodkov prebivalcev z nižjimi skupnimi dohodki.

BK presenetljivo ugotavlja, da ima prostovoljno zavarovanje vrsto negativnih vplivov na pravičnost in učinkovitost, med drugim spodbuja ponudbo alternativnih oblik zdravljenja, preusmeritev državljanov k manj učinkovitim oblikam zdravljenja, zmanjševanje vloge splošnega zdravnika, zmanjšanje samoomejevanja $v$ povpraševanju ipd. Takšne trditve brez dokazov so dejansko paternalistične vrednostne sodbe, ki pomenijo podcenjevanje sposobnosti proste presoje posameznika o tem, kaj je zanj najprimerneje. BK nadalje trdi, da je prostovoljno zavarovanje razbremenilo ljudi z visokimi prihodki na račun tistih z nizkimi, istočasno pa pozablja, da na drugem mestu trdi, da $20 \%$ zavarovancev povzroča $80 \%$ vseh stroškov. Kaj pa, če je teh $20 \%$ zavarovancev $v$ razredu z najnižjimi dohodki? Ali v tem primeru revnejši prebivalci ne dobijo bistveno več, kot prispevajo? Ali je $\vee$ tem primeru sistem prostovoljnega zavarovanja še regresiven? Netokoristi ni mogoče ocenjevati samo pri plačilih ali samo pri prejemkih, treba je oceniti tako prispevke kot koristi (zdravstvene izdatke). Trditev je še posebno sporna, če ni podprta z nobenim empiričnim podatkom.

Če sprejemamo izhodišče, da je treba trg prostovoljnega dopolnilnega zavarovanja reformirati, pa to še ne pomeni, da je nujna in upravičena njegova ukinitev in administrativna transformacija premij $\vee$ obvezni prispevek (davek) za zdravstveno zavarovanje. Večja družbena pravičnost financiranja zdravstva je vsekakor zaželena, kljub temu pa se postavlja legitimno vprašanje, ali je predlagana sprememba financiranja najboljši način za povečanje pravičnosti in ali je pravičnost edini motiv za predlagano reformo. Ali ne bi kazalo prej podrobneje opredeliti sveženj dobrin zdravstvenega varstva, ki bodo dostopne $v$ okviru obveznega zavarovanja? Pri tej opredelitvi bi morali predvsem izhajati iz dveh osnovnih postulatov: i) $\vee$ obveznem zavarovanju bi morale biti predvsem dobrine, ki za zavarovance pomenijo največje finančno tveganje in ga sami praviloma ne bi mogli financirati; ${ }^{9}$ ii) nemogoče je zagotoviti 100-odstotno pokritje za celoten sveženj obveznega zavarovanja, ker v takem primeru noben sistem zavarovanja ne more zagotoviti zadostnih finančnih sredstev. Šele na podlagi odgovora na ti dve vprašanji bi se bilo smiselno pogovarjati o tem, v kolikšnem obsegu ukiniti sedanje prostovoljno zavarovanje, ki se mora brez dvoma spremeniti.

Pisce BK predvsem motijo visoki presežki, ki sta jih zavarovalnici oblikovali doslej (v obdobju 1999-2002 so presežki znašali 40,7 mrd. SIT, od česar je šel večji del $v$ rezerve) in ki bi jih $v$ sistemu davka lahko tekoče uporabili za financiranje izvajalcev. Za zdravstveni sistem bi to pomenilo enkratno injekcijo dodatnih sredstev, poleg tega pa bi se z davkom letno zbralo še pribl. 65 mrd. SIT, kolikor so leta 2002

$9 \mathrm{~V}$ dosedanjem zakonu o zdravstvenem zavarovanju so odstotni deleži pokritja stroškov zdravstvenih storitev določeni bolj ali manj mehanično in po socialnih, ne zavarovalniških kriterijih. 
znašale premije; postavlja pa se vprašanje, kakšne bi bile posledice te navidezno nevtralne operacije. Predvsem bi zavrli nadaljnji razvoj zavarovalniškega trga in povečali delež javnega sektorja v BDP. Dopolnilno zavarovanje ima pozitivne učinke, saj se:

- razvijajo zavarovalnice, ki poslujejo po načelih zavarovanja tveganj, kar v aktuarskem smislu ne velja za obvezno zavarovalno blagajno, to pa deluje pozitivno na zavarovance $v$ smislu večje skrbi za preprečevanje bolezni (kot posledice kajenja, pitja, nevarnih športov) in manjšega povpraševanja po ne vedno potrebnih zdravstvenih storitvah (torej po načelu, kot ga predlaga Kornai);

- ustvarja kapitalska baza (rezerve) za prihodnje financiranje zdravstvenih izdatkov, ki v prispevnem sistemu preveč sloni na sistemu sprotnega kritja;

- statistično znižuje delež javne porabe $v$ BDP, ker se plačila dopolnilnega zavarovanja ne izkazujejo $v$ javnem sektorju. Transformacija sedanjih premij zavarovanja $\vee$ prispevek (davek) bo avtomatično povečala delež javnega sektorja za 1,2 \% BDP. ${ }^{\mathbf{1 0}}$

Učinkovit sistem financiranja zdravstva mora vedno biti kombinacija javnega obveznega zavarovanja ( $v$ večjem delu) in prostovoljnega dopolnilnega zavarovanja ( $v$ manjšem delu), vendar brez ideoloških predsodkov o prednosti enega sistema nad drugim. S predlaganimi spremembami financiranja BK dejansko ustvarja vtis, da je osnovni problem zdravstvene politike distribucija, namesto da bi to bila učinkovitost zdravstvenega sistema, seveda ob ustrezni pravičnosti financiranja.

\subsection{Regulativni vidik reforme}

Del BK, ki se ukvarja z regulativo, je najkoristnejši del knjige. $\vee$ tem delu je treba predvsem omeniti seznam modelov za plačevanje izvajalcev (cilj 2: razporejanje sredstev po potrebah državljanov) in predloge za večjo učinkovitost upravljanja na makronivoju (cilj 5: večja učinkovitost upravljanja in regulacije sistema zdravstvenega varstva). Ni se mogoče sicer strinjati z izrazom »razporejanje sredstev«, ki implicitno kaže na proračunsko in razdeljevalno logiko avtorjev, ker gre dejansko za plačevanje storitev (izvajalcem), za kar v bistvu vedno gre, ko obvezne ali prostovoljne zavarovalnice sklepajo pogodbe z izvajalci.

10 Predlog uvedbe zdravstvenega prispevka očitno tudi predvideva, da se bo za globalni znesek prispevka zmanjšala osnova za dohodnino (str. 81). Ob povprečni efektivni globalni stopnji dohodnine $20 \%$ to pomeni izpad dohodnine za okoli $13 \mathrm{mrd}$. SIT. 
$\checkmark$ cilju 2 je prikazanih 7 modelov plačevanja ter njihove prednosti in pomanjkljivosti, in sicer:

1. plačilo po ceni storitve,

2. plačilo po oskrbnem dnevu,

3. plačilo po primeru,

4. plačilo po skupinah podobnih primerov (SPP) oz. po zahtevnosti primera,

5. proračun,

6. glavarina in

7. plačilo za sveženj obravnave.

Različni modeli plačevanja so $v$ bistvu iskanje najustreznejše definicije produkta in njegove cene, ki jih je $v$ zdravstvu še posebej težko opredeliti, če upoštevamo, da gre tehnološko za več kot 7000 možnih postopkov. ${ }^{11}$ Praksa tujih zdravstvenih sistemov je pokazala, da je za bolnišnično zdravljenje najboljši model prospektivni plačilni sistem, pri katerem je z bolnišnicami dogovorjeno plačilo po skupinah podobnih primerov, ${ }^{12}$ ki izhaja iz določenih diagnostičnih skupin (diagnostic related groups $-D R G),{ }^{\mathbf{3}}$ in ta model se priporoča tudi za naš sistem. Prednost tega modela je, da izvajalce spodbuja $k$ iskanju notranjih rezerv, zmanjševanju ležalnih dob in prehodu na ambulantni (dnevni) način zdravljenja $v$ veliko primerih, kjer so se doslej pacienti zdravili bolnišnično. Ker so bolnišnični stroški največji del zdravstvenega proračuna, je z novim sistemom mogoče pričakovati precejšnjo racionalizacijo in prihranke. Prospektivni sistem plačevanja po skupinah podobnih primerov ima pred drugimi modeli tudi prednost, da se finančno tveganje med izvajalci in plačniki (zavarovalnicami) enakomerno razdeli, medtem ko je pri retrospektivnem plačevanju po storitvi večji del tveganja na plačniku. Za zdravnike $v$ osnovnem zdravstvu sistem DRG ni primeren, ker na tej stopnji ni mogoče dovolj natančno opredeliti začetek in konec postopka, kot je to mogoče za bolnišnično zdravljenje. Za osnovno zdravstvo se zato predlaga model glavarine, ki pa je primeren predvsem za enote $z$ večjim številom pacientov (npr. ZD), medtem ko je za individualne zdravnike (zasebnike) manj priporočljiv glede na vedno prisotno možnost, da pri prosti izbiri zdravnika pacienti izberejo drugega zdravnika in s tem prejšnjega spravijo $\vee$ finančne težave. $\vee$ primeru zasebnikov je zato primernejši sistem plačila po

11 T. i. sistem CPT (current procedural terminology system); Phelps (1997, str. 428).

12 Trenutno je pri nas opredeljenih samo 9 primerov za glavne specialnosti, in sicer: internistika, kirurgija, pediatrija, ginekologija, okulistika, otorinolaringologija, dermatologija, rehabilitacija in onkologija. $V$ jeziku ekonomistov bi lahko rekli, da je definicija produkta, in s tem tudi cene, bistveno pregroba za racionalno gospodarjenje.

$13 \mathrm{~V}$ ameriškem sistemu Medicare je opredeljenih 470 diagnostičnih skupin (Phelps, 1997), v slovenskem sistemu pa bo menda razvitih 600 skupin (BK, str. 120). Zanimivo je, da je slovenski antitržni sistem prevzel model plačevanja iz najbolj tržno naravnanega sistema v svetu. 


\section{Marko Kranjec}

\section{Slovenski zdravstveni sistem in javni sektor}

storitvi, o katerem se BK ne opredeljuje. V delu BK, ki obravnava modele plačevanja, so številni primeri delovanja ekonomskih zakonov, ki jih sicer BK vehementno zanika.

Prospektivni model plačevanja zahteva zbrane podatke o kliničnih obravnavah in stroških, ki so se doslej zbirali nepopolno ali se sploh niso zbirali in jih je malokdo uporabljal za analize. Pričakovati je, da bodo pred vpeljavo modela podrobno simulirani doslej zbrani podatki in ocenjeni potencialni finančni prihranki. Tudi za ta del projekta bi bilo primerneje, če bi ga izvedli pred uvedbo novega zdravstvenega prispevka (davka).

Zdravstvo je dejavnost, pri kateri je regulacija neizogibna ne glede na to, ali je v celoti organizirano $v$ javnem sektorju ali pa imamo mešani sistem javnega in zasebnega zdravstva. ${ }^{14} \mathrm{~V}$ grobem bi regulacijo na področju izvajanja zdravstvenih storitev lahko razdelili na ekonomsko in zdravstveno regulacijo. Pri ekonomski regulaciji, ki nas tukaj edino zanima, gre za nadzor nad stroški in cenami storitev (s pomočjo modelov plačevanja) in za ugotavljanje učinkovitosti in produktivnosti poslovanja (produktivnosti zdravnikov, bolnišnic, učinkovitosti zdravljenja itd.). Ekonomska regulacija je običajno usmerjena $v 4$ večja področja: i) regulacija sklepanja pogodb in izbire izvajalcev, ii) regulacija plačevanja storitev izvajalcev, iii) regulacija porabe in plačevanja zdravil ${ }^{\mathbf{1 5}}$ in iv) regulacija investicij $v$ zdravstvo. BK našteva področja regulacije, od katerih so posebno pomembne regulacija cen, regulacija delovanja plačnikov (tudi glede zlorabe monopolnega položaja zavarovalnic), regulacija delovanja izvajalcev in, delno, regulacija kapacitet (na tem področju bi bilo smiselno pustiti več avtonomije zasebnemu sektorju). Regulacije teh področij ne more $v$ celoti urediti zakon, temveč jih je treba opredeliti s podzakonskimi akti, za katere morajo biti odgovorne regulatorne institucije. Tehnična regulacija $v$ obliki določanja kakovosti in dostopnosti je seveda tudi sestavni del regulacije, ki pa je samo posredno del ekonomske regulacije.

Težko je oceniti, kako so posamezne institucije v Sloveniji izvajale ekonomsko regulacijo $\vee$ preteklosti. Glede na opise $\vee B K$ je mogoče domnevati, da je bila regulacija prepuščena posameznim institucijam: za plačevanje (modeli) in sklepanje pogodb je skrbel ZZZS, urad za zdravila sestavlja listo zdravil, investicije določa MZ, zbiranje podatkov opravlja Inštitut za varovanje zdravja, vse skupaj pa je obremenjeno z zakonodajo, ki zavodom, farmacevtom in industriji zdravil daje praktično popolno avtonomijo in možnost izsiljevanja dodatnih sredstev po regionalnih ključih in glede na kapacitete izvajalcev. BK govori o tem kot o sistemu, ki je bil usmerjen v

14 Tudi za ameriški zdravstveni sistem velja, da je sektor $z$ največjo stopnjo regulacije $v$ vsem gospodarstvu.

$15 \mathrm{Da}$ izvajalci in drugi lobiji, ki imajo korist od sedanjega nepreglednega sistema, ne marajo ekonomske regulacije, dokazujejo razprave o tem, kakšna nevarnost grozi bolnikom, če bodo morali jemati generična zdravila namesto dragih originalov. Prihranki, ki jih je mogoče doseči z generiki, pa bi pri tem znašali nekaj deset mrd. SIT. 
izvajalce in ne $v$ paciente. Primerneje bi bilo govoriti o sistemu, ki ni poznal ustrezno koordinirane ekonomske regulacije, za kar sta primarno odgovorna ZZZS kot največja "zavarovalnica" in MZ. V prihodnje se noben izvajalec ne bi smel počutiti popolnoma brezskrbno glede zagotavljanja sredstev; to naj bo odvisno predvsem od njegovega dela in učinkovitosti.

Uvedba novih modelov plačevanja izvajalcev, uvedba liste cenejših zdravil ter predlog za participacijo pri zdravilih in pri obisku splošnega zdravnika so zato koraki $\checkmark$ pravo smer, zavedati pa se je treba, da to ni samo stvar pogajanj med ZZZS ter bolnišnicami in zavodi, temveč je del širšega kompleksa ekonomske regulacije zdravstva, ki je bila doslej pomanjkljiva in razpršena med različnimi institucijami, predvsem pa svoje naloge nista opravila ZZZS in MZ kot osnovna regulatorja zdravstvenega sistema. Kaj je vzrok za to, je težko presojati, eden od osnovnih pa je prav gotovo pomanjkanje interesa za omejevanje stroškov, saj so tako izvajalci kot obvezna zavarovalnica $v$ javnem sektorju. Neizpodbitno dejstvo je, da ekonomsko regulacijo $\vee$ zdravstvu potrebujemo in je ne moremo nadomestiti $s$ pozivanjem na zavest, z ideološkim apriorizmom in ignoriranjem ekonomskih omejitev. Z ustrezno regulacijo je $v$ bistvu nepomembno, iz katerega sektorja sta izvajalec in zavarovalnica.

\subsection{Upravljavski vidik reforme}

BK se na kratko dotika tudi problema upravljanja $v$ naših zdravstvenih zavodih. Pravilno se ugotavlja, da je menedžment $v$ zdravstvu slabo razvit, deloma zaradi predpisov in deloma zaradi napačne selekcije menedžerjev. $\vee$ večini zdravstvenih zavodov so na vodilnih mestih zdravniki, ki za upravljanje nimajo ustreznega znanja. Sedanja zakonska ureditev $v$ zdravstvenih zavodih ohranja proračunsko logiko, zato so najprej potrebne zakonske spremembe, ki bodo menedžmentu zavodov omogočile večjo avtonomijo tako do plačnikov, da bodo lahko poslovali po podjetniških načelih (seveda v okviru dogovorjenih pogodb z zavarovalnicami), kot tudi do zaposlenih zdravnikov. Skoraj nič ni povedano o morebitni privatizaciji javnih zdravstvenih zavodov $\vee$ zasebne ali polzasebne institucije (npr. v neprofitne klinike, zavode ipd., podobno kot $v$ tujini). Spremeniti je treba tudi funkcije svetov zavodov, ki so sedaj pogosto zavora za racionalizacije, ki jih predlaga menedžment. Z razmišljanji in predlogi BK se je $v$ večjem delu mogoče strinjati.

\section{Kako naprej?}

BK je lahko izhodišče za nadaljnje delo, pri čemer bi kazalo prej odgovoriti na številna vsebinska vprašanja, ki se jih BK ne dotika. Prva prednostna naloga ne bi smela biti sprememba financiranja zdravstva, tj. transformacija prostovoljnega dopolnilnega zavarovanja $\vee$ novi zdravstveni davek. To je lahko kasnejši rezultat, če 
Marko Kranjec

\section{Slovenski zdravstveni sistem in javni sektor}

bi druge analize pokazale, da je to smiselno in upravičeno s stališča prihodnjega razvoja zdravstvenega sistema in gospodarstva nasploh, ki bo $v$ skladu s članstvom $\checkmark$ EU socialno-tržno usmerjeno (poudarek je na tržno!) in bo moralo zagotavljati makroekonomsko stabilnost. Prva prednostna naloga bi morala biti povečevanje učinkovitosti zdravstva, ki je ni mogoče doseči samo z nekaj zakoni ali z ozaveščenostjo zdravnikov ${ }^{16}$ in javnih uslužbencev, temveč s konkurenco med javnimi zavodi, med javnimi in zasebnimi izvajalci, s primerno regulacijo celotnega sektorja zdravstva in z upravljanjem javnih zavodov v skladu s podjetniškimi načeli. ${ }^{17}$

Reforma bi morala izhajati iz naslednjih predpostavk, ki se deloma razlikujejo od izhodišč BK:

I) financiranje zdravstvenega varstva je kombinacija obveznega zavarovanja ( $v$ večjem delu) in prostovoljnega dopolnilnega zavarovanja;

II) nobenemu zavarovancu iz obveznega zavarovanja ni mogoče $v$ celoti zagotoviti 100-odstotnega pokrivanja stroškov; vsebinska in količinska opredelitev svežnja pravic je stvar politične odločitve, ki mora upoštevati ekonomske omejitve;

III) izvajanje zdravstvenih storitev opravljajo javni in zasebni izvajalci, pri čemer ni apriorno zagotovljena večja vloga ali delež javnega sektorja; zdravstveni izvajalci so $v$ odnosu do financerjev enakopravni; pospešuje se konkurenčnost in zagotavlja dinamično prilagajanje izvajalcev $\vee$ prostoru in času;

IV) razvoj zdravstvenih kapacitet je predmet nacionalnega planiranja, pri čemer je dopustno in zaželeno ne samo investiranje javnega, temveč še posebno zasebnega sektorja ( $\mathrm{z}$ zdravstvena "podjetja« in opremo);

V) zdravstveni sektor ne posluje na prostem trgu, temveč ga država okvirno regulira in planira (izvajalci, zavarovalnice, lekarne, proizvajalci zdravil).

Na podlagi teh izhodišč bi bilo treba delovati predvsem $\vee$ naslednjih petih smereh:
a) pregled učinkovitosti in organiziranosti zdravstvenih izvajalcev,
b) pregled finančnih rezerv $\vee$ sedanjem sistemu in analiza alternativnih sistemov financiranja,
c) vzpostavitev celovitega sistema regulacije,
d) zakonodajne in institucionalne spremembe,
e) druge aktivnosti.

16 Ozaveščenost izvajalcev je eden od argumentov v BK. O tem dovolj zgovorno priča najnovejši škandal pri nakupu operacijskih miz v KC.

17 Za zasebne izvajalce je poslovanje po "podjetniških" načelih samo po sebi razumljivo in pogoj obstanka. 


\section{Slovenski zdravstveni sistem in javni sektor}

$\checkmark$ nadaljevanju podajamo nekatere predloge za potrebne analize in ukrepe.

\section{Ad a) Ugotavljanje učinkovitosti in organiziranosti izvajalcev}

1. Izdelava statistične baze podatkov za nadzor produktivnosti in plačevanje $v$ različnih modelih plačevanja.

Iz statistike o izvajanju storitev je treba zbrati podatke o obravnavah na vseh nivojih zdravljenja, in sicer:

- $\quad v$ osnovnem zdravstvu o številu pacientov, pri katerih se bo plačevalo z glavarinskim modelom,

- $\quad v$ sekundarnem zdravstvu o številu akutnih primerov, pri katerih se bo plačevalo po modelu SPP (DRG),

- $\quad v$ sekundarnem zdravstvu o številu neakutnih primerov, pri katerih se bo plačevalo po modelu oskrbnega dne,

- $\quad v$ terciarnem zdravstvu o številu primerov, pri katerih se bo plačevalo po modelu SPP ali po oskrbnem dnevu,

- $\quad v$ specialističnih zavodih o številu in vrsti primerov ter modelih plačevanja (verjetno po oskrbnem dnevu ali po opravljeni storitvi),

- pri zdravnikih zasebnikih o številu primerov in modelu plačevanja (verjetno po opravljeni storitvi),

- podatke o morebitnih drugih storitvah (urgentne storitve ipd.).

Podatke o tem bi bilo treba zbrati na nivoju zavoda (ZD, bolnišnica, laboratorij itd.) in na nivoju zdravnika (ali ekipe zdravnikov). Tak pregled, izdelan na osnovi storitev enega ali dveh let, bi bil osnova za oceno stroškov zdravstvenega sistema. Ceno posamezne storitve bi bilo treba izračunati iz stroškov $v$ preteklosti in iz primerjave $s$ stroški podobnih storitev $\vee$ tujini. Iz predvidevanj potrebnega obsega zdravstvenih storitev $v$ prihodnosti bi bilo iz te baze podatkov mogoče dobro preverjati, kakšne bodo letne finančne potrebe, ločeno po zdravnikih, zavodih in $v$ globalu. $S$ tem bi opustili planiranje na osnovi globalnega proračuna, ki je zelo nezadovoljiv instrument, s katerim lahko izvajalci stalno manipulirajo. Takšna baza podatkov tudi omogoča preveritev produktivnosti zdravnikov in zavodov, kar je nujno potreben podatek plačniku (ZZZS in zasebnim zavarovalnicam) pri letnem sklepanju pogodb. če podatkov ni mogoče zbrati za celotno zdravstvo, bi bilo treba izbrati nekaj izvajalcev (bolnišnic, ZD, zasebnikov) in iz teh podatkov oceniti letne stroške, nato pa jih aplicirati na celotno zdravstveno mrežo. Prednost tega pristopa je, da je mogoče dosti natančnejše predvidevanje sprememb obsega storitev in cen ter njihovega prilagajanja inflaciji namesto pavšalnega dviganja obsega plačil izvajalcem za stopnjo letne inflacije. Če je takšna statistika že razpoložljiva, bi jo bilo treba samo ustrezno obdelati. Izdelovanje baze podatkov bo verjetno trajalo več mesecev. 


\section{Marko Kranjec}

\section{Slovenski zdravstveni sistem in javni sektor}

Na podoben način, kot je bil $\vee$ BK simuliran izračun posledic prispevka za različne dohodke, naj se izdela simulacija posledic različnih modelov plačevanja za zdravstveni proračun.

\section{Sprememba plačne politike $v$ zdravstvu}

S spremenjenim načinom plačevanja zdravstvenih storitev bi se morala spremeniti pogajanja o plačah zdravnikov. $V$ obliki, kot so potekala doslej, je bila država v pogajanjih vedno talec grožnje sindikata, da bodo zdravniki prenehali z delom. Z novimi modeli plačevanja bodo zdravniške plače sestavni del cene storitve, zato se je mogoče pogajati samo o cenah teh in o tem, ali te cene prenesejo plače, kot si jih zamišljajo zdravniki. S širjenjem zasebnih izvajalcev se bo grožnja javnih zavodov in sindikata $v$ vsakem primeru zmanjševala. Preveriti bi bilo treba možnost čimprejšnje uvedbe plačevanja zdravnikov po individualnih pogodbah $v$ vseh primerih, kjer je možno meriti njihove učinke. Če je glede tega potrebna sprememba zakonodaje, bi moralo MZ takoj uvesti spremembe.

\section{Dopolnitev strategije razvoja mreže izvajalcev}

Strategija razvoja mreže zahteva podatke, po občinah ali krajih, o lokaciji izvajalcev in njihovi obremenjenosti. Verjetno je večina teh podatkov že zbrana in analizirana. Potrebni so podatki o izvajalcih na vseh nivojih in o ustanovah, ki se ukvarjajo z bolniki izven zdravstvene mreže.

Mreža zdravstvenih izvajalcev je zelo odvisna od odločitev $\vee$ preteklosti in ne ustreza vedno spremenjenim razmeram $v$ sedanjosti. Potrebna bi bila analiza obremenjenosti zavodov, ki bi pokazala, ali je obstoj vseh zavodov še vedno upravičen ${ }^{18}$ in ali ne bi bilo mogoče doseči prihrankov, ki jih omogoča večja mobilnost pacientov (ob vsem upoštevanju pravočasne in ustrezne dostopnosti). Z večanjem števila zdravnikov zasebnikov tako $v$ splošni praksi kot specialistov, ki svojo dejavnost lahko izvajajo v manjših krajih, se postavlja vprašanje upravičenosti večjih organizacij (zdravstvenih domov) in njihovih predvidoma večjih stroškov.

Ad b) Ugotavljanje finančnih rezerv $v$ sistemu in analiza alternativnih sistemov financiranja

1. Izdelava analize o vplivu določitve spodnjega minimuma in zgornjega maksimuma osnove za zdravstveni prispevek

Večina evropskih držav ima osnovo za zdravstveni prispevek omejeno navzgor (gre torej za omejeno solidarnost). Koliko manj sredstev bi $v$ tem primeru zbrali $\vee$ Sloveniji in s katerimi viri (davki) bi jih lahko nadomestili? Pri nas je poseben problem tudi prosta izbira prispevne osnove (spodnji minimum) za zavarovance, ki niso uslužbenci (npr. podjetniki, svobodni poklici, športniki ipd.), s čimer ti poklici

$18 \mathrm{~V}$ BK je npr. omenjeno zmanjševanje števila rojstev ob nespremenjenem številu pediatrov. 


\section{Slovenski zdravstveni sistem in javni sektor}

zmanjšujejo svoje prispevke za zdravstvo. Vprašanje ni nepomembno, ker velik del zavezancev za prispevke, posebno zasebnikov, kot osnovo prijavlja bistveno nižjo osnovo, kot $v$ resnici znašajo njihovi prejemki (s tem so tudi diskriminirani zaposleni, ki vse prejemke dobivajo $v$ obliki brutoplač).

2. Vpliv uvedbe časovne omejitve in (odstotnega) deleža znižanja nadomestil za čas bolezni

Po nepreverjenih podatkih nadomestila za čas bolezni pomenijo $56 \%$ vseh izdatkov osnovnega zdravstva; dnevno je zaradi bolezni z dela odsotnih 35.000 oseb. Odgovoriti je treba na vprašanje, kako je mogoče zmanjšati ta del stroškov, da bo primerljiv s prakso v EU (stimulacija za prisotnost?). Kolikšni bi lahko bili prihranki po različnih variantah?

\section{Razmejitev med izdatki za socialno varnost in izdatki za zdravstvo}

Izdatki, ki imajo pretežno značaj socialnih izdatkov (nadomestila brezposelnim za čas bolezni, dolgotrajna nega $\vee$ primeru kroničnih bolezni ipd.) naj se prenesejo na resor sociale, s čimer se lahko razbremeni proračun zdravstva.

4. Izločitev posebnih tveganj iz obveznega zdravstvenega zavarovanja

Zdravljenje $v$ primeru avtomobilskih nesreč in $v$ primerih poškodb pri nevarnih športih bi bilo treba prenesti na obvezno avtomobilsko zavarovanje in na dodatno zavarovanje tistih, ki se ukvarjajo z nevarnimi športi. Kolikšni so možni prihranki?

\section{Analiza različnih modelov poravnavanja stroškov zdravljenja}

Ali bi uvedba plačevanja storitev pri zdravniku in kasnejše povračilo (reimbursiranje) od ZZZS (namesto fakturiranja storitev ZZZS) lahko pomenila prihranke zaradi manjšega povpraševanja? Zdravstveni sistemi EU uporabljajo zelo različne modele plačevanja.

6. Ocena možnih prihrankov predpisovanja generičnih zdravil

Študije kažejo, da je s predpisovanjem cenejših generičnih zdravil mogoče letno prihraniti med 2,5 in $10 \mathrm{mrd}$. SIT ob zagotavljanju enake kakovosti zdravstvenega varstva. ${ }^{19}$

7. Prenos pristojnosti glede pobiranja, izterjave in obračuna prispevkov za zdravstveno zavarovanje na ZZZS

Ali bi bilo smiselno pobiranje obveznih prispevkov prenesti na ZZZS? Ali bi bili $\checkmark$ tem primeru zaostanki pri plačevanju manjši? Za koliko bi se $v$ tem primeru povečali stroški ZZZS?

19 J. Bešter idr.: Raziskava o možnih prihrankih pri izdatkih za zdravila na recept v Sloveniji, IER, maj 2003. 


\section{Marko Kranjec}

\section{Slovenski zdravstveni sistem in javni sektor}

8. Izdelava strategije razvoja dopolnilnega (privatnega) zavarovanja

$\mathrm{Ne}$ glede na to, ali bo uveden zdravstveni prispevek (davek), je mogoče pričakovati, da bo dopolnilno zdravstveno zavarovanje $\vee$ prihodnje ponujalo več zavarovalnic, tudi iz tujine. Vprašanja, ki se ob tem postavljajo, so zlasti:

- koliko zavarovalnic prenese slovenski trg,

- ali naj bodo zavarovalnice na komercialni ali na vzajemni osnovi,

- ali potrebujemo spremembo zakona o zavarovalništvu oz. poseben zakon o zdravstvenih zavarovalnicah,

- kdo naj nadzira zavarovalnice s stališča konkurenčnosti, kartelnega dogovarjanja in zaščite potrošnikov,

- kakšna naj bo vloga privatnih zavarovalnic $v$ pogajanjih o sklepanju pogodb z izvajalci (neodvisne od ZZZS, partner?),

- ali pospeševati skupinsko zavarovanje (po podjetjih ali po geografskem načelu), tako da se razprši tveganje in znižajo zavarovalne premije,

- ali lahko zavarovalnice ustanavljajo tudi svoje zdravstvene zavode (po zgledu Health Maintenance Organisations - HMO), s čimer imajo večji vpliv na stroške izvajalcev,

- kakšen je $v$ tem primeru odnos med obvezno (ZZZS) in privatno zavarovalnico itd.

9. Izdelava analize o možnem segmentiranju zdravstvenega zavarovanja

Slovensko prebivalstvo je s stališča stroškov razdeljeno na 3 skupine: i) skupina, ki je socialno ogrožena (revni), v kateri je pribl. 200.000 prebivalcev. Ta skupina ni sposobna $\vee$ celoti financirati svojega zavarovanja. Ugotoviti bi bilo treba, kolikšna je njihova poraba storitev zdravstva $\vee$ razmerju do financiranja; ii) skupina delovno aktivnih prebivalcev (in njihovih družin). $V$ tej skupini je pribl. 1,5 mio. prebivalcev. Ugotoviti je treba, kakšna je njihova bilanca med financiranjem in porabo; iii) skupina starejših občanov in upokojencev (več kot 65 let, pribl. 350.000 prebivalcev). Ugotoviti je treba, kakšna je bilanca med stroški in prispevki v tej skupini. Analiza bi skušala ugotoviti, kolikšna solidarnost je potrebna med skupinami in ali bi bilo mogoče diferencirano definirati zdravstvene pravice za te skupine, posledica česar bi bilo različno dopolnilno zavarovanje.

10. Izdelava analize o vplivu novega zdravstvenega davka na pokojninske osnove bodočih upokojencev

Nekateri analitiki trdijo, da bo zaradi višje obremenitve brutoplač prišlo do manjših pokojninskih osnov in $s$ tem do nižjih pokojnin. Pokazati bi bilo treba konkretne izračune. 


\section{Slovenski zdravstveni sistem in javni sektor}

\section{Konkretna opredelitev ciljev promocije zdravja}

BK najavlja (str. 232) nacionalni program javnega zdravja za obdobje 2004 2010. V nacionalnem programu morajo biti opredeljeni konkretni kvantitativni cilji zmanjševanja bolezni in umrljivosti in ukrepi, ki bodo za to potrebni (morebitno povečanje davkov na cigarete, alkohol, ostrejša kontrola vinjenih voznikov ipd.), ter ocenjen potencialni netoprihranek (po odbitju stroškov promocije, pomoči ipd.), če bo prišlo do uresničitve ciljev.

\section{Ad c) Vzpostavitev celovitega sistema regulacije}

1. Ustanovitev oddelka za globalno regulacijo

MZ ali ZZZS bi morala vzpostaviti enoto, ki se bo ukvarjala izključno z ekonomskimi in finančnimi vprašanji oz. ekonomskim planiranjem, tj. predvsem:

- sklepanje pogodb z izvajalci (vrste pogodb, obveznosti partnerjev),

- vrste modelov plačevanja in določanje cen standardnih storitev in obravnav),

- delovanje izvajalcev (poslovanje po podjetniških načelih, razmerja med različnimi nivoji zdravstva),

- reguliranje liste zdravil in določanje cen,

- reguliranje kapacitet (v skladu s strategijo razvoja mreže),

- potrebne investicije in predvideni investitorji (javni sektor, zasebni sektor),

- spremljanje globalnih gibanj $\vee$ zdravstvenem sektorju in ažurno predlaganje ukrepov za korekcijo nepredvidenih odklonov na strani porabe,

- spremljanje kakovosti zdravstvene oskrbe (za to ni potrebna posebna agencija) in reševanje pritožb pacientov.

Za oblike in vrsto regulacije je mogoče dobiti izkušnje pri zdravstvenih sistemih $\checkmark$ tujini.

\section{Učinkovitejša regulacija cen zdravil in marž v lekarnah}

Ker gre za sektor, pri katerem je vstop $\vee$ dejavnost reguliran in omejen, ima država popolno pravico nadzirati in celo določati cene $\left.z d r a v i\right|^{\mathbf{2 0}}$ in marž. Preverjanje finančnega poslovanja lekarniških podjetij, način sklepanja pogodb z industrijo zdravil, nadzor nabav preko povezanih podjetij in nadzor porabe zdravil morajo postati del permanentnega delovanja ZZZS in MF. Obseg letnih stroškov za zdravila (pribl. 60 mrd. SIT) je tretja največja postavka zdravstvenega proračuna.

20 Analize kažejo, da so cene nekaterih generičnih zdravil naših proizvajalcev bistveno višje kot v tujini, kar morda lahko pojasnjuje uspešnost naših proizvajalcev. Cene naših generikov se pri nas običajno - in napačno - primerjajo s cenami tujih originalnih zdravil, ki so običajno precej dražja. 
Marko Kranjec

\section{Slovenski zdravstveni sistem in javni sektor}

\section{Ad d) Zakonske in podzakonske spremembe}

1. Sprememba zakonodaje, ki omejuje javne zavode pri poslovanju po podjetniškem principu

Spremeniti je treba vlogo svetov zavodov in vlogo menedžmenta. Menedžerjem (direktorjem) je treba dati vsa pooblastila, da zavode vodijo poslovno učinkovito, da spremljajo produktivnost zdravnikov in strokovnega osebja in tudi v celoti odgovarjajo za poslovne odločitve. Zdravniki so $v$ poslovnih zadevah in $v$ organizaciji dela zavoda podrejeni vodstvu.

2. Uvedba participacije za zdravila in za prvi obisk pri zdravniku

Ta predlog vsebuje že BK in ga je treba čim prej uresničiti. Participacija naj ne bo konfiskatorna, temveč edukativna, s čimer se bo zmanjšal moralni hazard pri potrošnji zdravil in pri nepotrebnih obiskih zdravnika.

3. Privatizacija javnih zavodov

Če obstaja interes zdravnikov za privatizacijo, bi bilo treba razmisliti o spremembi statusa javnega zavoda v zasebnega, ki bi posloval po koncesiji. Proračunski stroški (predvsem tisti, povezani s fiksnimi stroški stavb in opreme) bi se $v$ takem primeru lahko zmanjšali. Izdelati je treba analizo mogočih prihrankov po različnih scenarijih.

4. Druge spremembe zakonskih in podzakonskih predpisov

MZ naj izdela podroben seznam predpisov, ki bi jih bilo z reformo treba spremeniti.

\section{Ad e) Druge dejavnosti}

1. Izobraževanje zdravstvenih delavcev $v$ veščinah zdravstvene ekonomike in upravljanja

Po nepreverjenih informacijah trenutno nobena fakulteta $\vee$ Sloveniji nima sodobnega programa ekonomike zdravstva (health economics), kar je resna pomanjkljivost za učinkovitost te dejavnosti.

2. Vpeljava mednarodne klasifikacije zdravstvenih izdatkov po metodologiji OECD

Sedanja proračunska klasifikacija (plače, materialni stroški itd.) je bistveno pregroba za smiselno analitično proučevanje učinkovitosti zdravstvenih izdatkov ter izdatkov zavodov in njihove učinkovitosti. 


\section{Zaključek}

BK je za zdaj le osnutek reforme in je lahko izhodišče za resnejšo reformo, ki je vsekakor potrebna. Najprimernejša za nadaljevanje reforme bi bila izdelava BK II, v kateri bi bili prikazani rezultati analiz zgoraj navedenih (in morebitnih dodatnih) področij in predlogov, in šele na tej podlagi bi bila smiselna razprava o morebitni spremembi sistema financiranja.

BK daje vtis, da je najpomembnejši del reforme sprememba sistema financiranja, s katerim naj bi bili rešeni vsi nakopičeni problemi zdravstva, ki je organizirano in upravljano z logiko preteklega gospodarskega in družbenega sistema in ki naj bi takšno ostalo tudi po reformi. Brez rešitve teh vprašanj obstaja resna nevarnost, da bo prenos financiranja iz dopolnilnega zavarovanja na obvezni prispevek samo kratek predah za zdravstvo, nato pa se bodo vsi problemi ponovili, vendar na višjem nivoju.

\section{Literatura:}

- Bela knjiga: Zdravstvena reforma, osnutek, MZ, 2003.

- Arrow, K. (1963), Uncertainty and the welfare economics of medical care; American Economic Review, Vol. LIII, št. 5.

- Kornai, J., idr. (2001), Reforming the State: Fiscal and Welfare Reforms in Post-socialist Countries (poglavje 6: The borderline between the spheres of authority of the citizen and the state: Recommendations for Hungarian health reform); Cambridge University Press.

- Kranjec, M. (2003), Davki in proračun; Fakulteta za upravo, Univerza v Ljubljani.

- Mossialos, E., Dixon, A., idr. (2002), Funding health care: Options for Europe; Open University Press, Buckingham.

- Pauly, M. V. (1986), Taxation, health insurance, and market failure in the medical economy; Journal of Economic Literature, vol. XXIV, junij.

- Phelps, C. E. (1997), Health Economics, 2. izd.; Addison Wesley.

- Stiglitz, J., Weiss, A. (1981), Credit rationing in markets with imperfect information; American Economic Review, Vol. 71, št. 3.

Dr. Marko Kranjec je zaposlen kot izredni profesor na Fakulteti za upravo. Doktoriral je s področja javnih financ. Več let je služboval kot raziskovalni sodelavec in nadalje kot raziskovalni svetnik na Inštitutu za ekonomska raziskovanja (IER) pri Ekonomski fakulteti v Ljubljani, OECD v Parizu ter Svetovni banki v Washingtonu. 
Marko Kranjec

Slovenski zdravstveni sistem in javni sektor

\section{SUMMARY}

\section{The Slovenian Healthcare System and the Public Sector}

The paper is a critical review and analysis of the White Book (WB) on the reform of the healthcare system in Slovenia (prepared by the Ministry of Health). While the author agrees with the need for reform, he considers the proposals contained in the WB to be too narrow, ideologically biased, and essentially limited to the question of health insurance financing.

Healthcare systems in practically all developed countries are presently faced with financial and budgetary constraints that reflect changes in demographics, new social patterns of life, improved technology of healthcare treatment and better drugs. Countries in transition in Central and Eastern Europe must, in addition to these common factors, reorient their healthcare systems from the philosophy that (at least in theory) guaranteed complete and free coverage of healthcare needs to everybody, to a system that will better reflect market realities, while simultaneously guaranteeing a politically acceptable level of solidarity and social justice.

The author believes that the WB is seriously flawed in its economic analysis and policy implications. Economic theory is today unanimous that a free market in medical care leads to socially unacceptable outcomes. This is the main reason behind mandatory healthcare financing schemes that are practised in most countries of the EU. These mandatory financing schemes, however, do not exclude the desirability of private financing of supplementary health insurance for services that are not covered by the public health insurance. Public health insurance also does not imply only public provision of health services, which the WB believes should be the institutional solution in Slovenia. In the author's opinion, the healthcare system should be reformed in the direction of more competition among public and private providers and a greater variety of insurance packages that should be offered by commercial or by non-profit (mutual) insurance companies. In the unreformed institutional setup that is assumed by the WB, it is impossible to improve the efficiency of providers and consequently to achieve the economies necessary to balance the health budget.

The WB lays the emphasis of the reform on the transformation of the present supplementary insurance financing into a compulsory contribution that would become the revenue of the Institute for Health Insurance, a public body that at present finances roughly $90 \%$ of all healthcare expenditures. It is 
believed that this transformation would achieve two goals: i) financing would better reflect objectives of social justice (contributions would be proportional to gross salaries, while the present voluntary insurance is based on fixed premiums), and ii) more resources would be available since no reserves would be needed, compared to the present system in which insurance companies must set aside reserves for risks. Implied in these proposals is also the assumption that resources would be employed more efficiently.

The author believes that all these assumptions are deficient and based on wishful thinking rather than the facts. He advocates a system where competition will be promoted, both in the financing and the provision of healthcare. Regulation, rather than ideology, should guide healthcare policy. Regulation of prices, better models for payment of providers, supervision of profit margins of drug distributors (that are, in most cases, local monopolies), and more efficient management of public health providers should be the primary orientation of the healthcare system reform, rather than the suppression of the private market in insurance and health services provision.

The author proposes actions in several directions in order to improve the efficiency of the system, inter alia: i) inventory of existing inefficiencies in the public sector, ii) inventory of possible economies that would result from better payment models and from clearer delimitation of financial obligations between social and healthcare policy, iii) introduction of efficient regulatory policy, iv) a thorough review of existing legislation with the view to minimizing costs, and $v$ ) other actions that would promote economic criteria, instead of social considerations that were the characteristic of the previous social and economic system. 